\title{
Inflammatory fibroid polyp，隆起型異型上皮巣を
}

\section{併存した胃癌の 1 例}

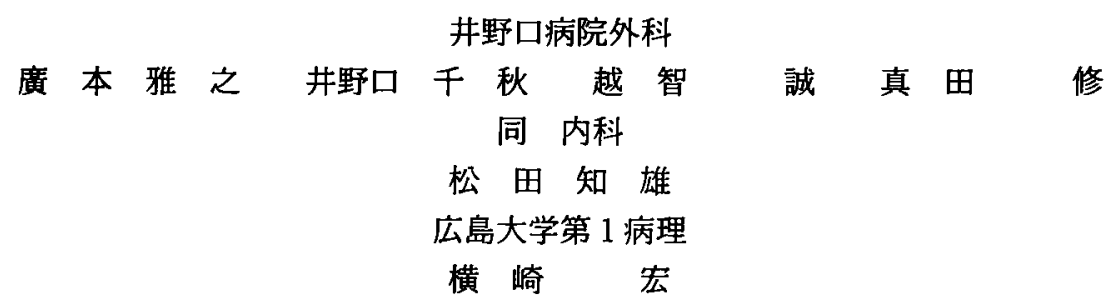

比較的まれな胃 inflammatory fibroid polyp(以下 IFP)，および隆起型異型上皮巣(以

下 ATP, adenoma）を併存した胃癌の1例を経験したので報告する.

症例は81歳，女性. 腹部膨満感と水様性下痢を主訴に来院.上部消化管造影・内視鏡 において, 十二指腸球部へ浸潤した幽門部の 2 型癌, そのやや口側に山田III型ポリープ に類似する球状の粘膜下腫瘍, さらに体部小彎に小さな半球状の隆起性病変を認めた。 胃严全摘術を施行。病理組織学的検索では, それぞれ，中分化型胃癌 $\left(\right.$ tub $\left._{2}, \mathrm{ss}\right), \mathrm{FFP}$, ATPであった。

胃 IFP と胃癌との合併例の報告は，本邦において現在までに22例であり，比較的まれ なものである. 年齢は平均 62.4 歳で, やや男性に多くIFPの多くは $1 \mathrm{~cm}$ 以下であり, 胃 癌は早期癌が多くみられた，両者の合併については，種々の説があるが，胃癌の粘膜背 景を考える際, 示唆に富む症例と思われた。

索引用語：胃癌, Inflammatory fibroid polyp (IFP), 隆起型異型上皮巣（ATP, adenoma)

\section{緒 言}

胃癌において, 胃内併存病変, とりわけ非癌性病変 との共存例について検討することは, 癌の発生母地を 解析するうえからも，きわめて興味深いことと考える.

今回, 比較的まれな胃 IFP，および ATP(adenoma) を併存した胃癌の 1 例を経験したので文献的考察を加 え報告する。

\section{症例}

患者:81歳, 女性.

主訴：腹部膨満感，下痢。

既往歴：特記すべきことなし.

家族歴：特記すへきことなし.

現病歴：数年前より，時に下痢と便秘をくり返して いた。今回, 平成 5 年 6 月 23 日より, 腹部膨满感が出 現し，同時に水様性下痢もみられたため，6月26日，

1994年 5 月 6 日受付 1994年 9 月19日採用
当院受診, 精査加療目的で入院となった。

入院時現症：体格小柄, 栄養良好. 眼瞼結膜に貧血 なく, 眼球結膜の黄染もなかった. 胸部理学的所見で 異常を認めず．腹部は平坦，軟で，膨隆はなく，腫瘤 も触れず，压痛も認められなかった．全身の表在性リ ンパ節の腫脹はなく，浮腫等もみられなかった。

入院時検查所見：入院時に行った血液一般, 生化学 検査では異常なく，尿，便検査でも特記すべき所見は みられなかった。

上部消化管造影所見：2 重造影にて, 胃幽門部から 十二指腸球部にかけて，後壁大彎よりに，周庭を有し， 中央に謴場を形成した 2 型進行癌を認めた。また，そ のやや口側には表面平滑で楕円形の隆起性病変がみら れた。ささに，十二指腸下行脚の入口部には，矢印の ごとく，大きな息室も認めた（図 1 左).

後壁薄層像では, 幽門部から十二指腸球部にかけて, 周囲の急峻な立ち上がりと凹凸不整な漬場面とを有す 

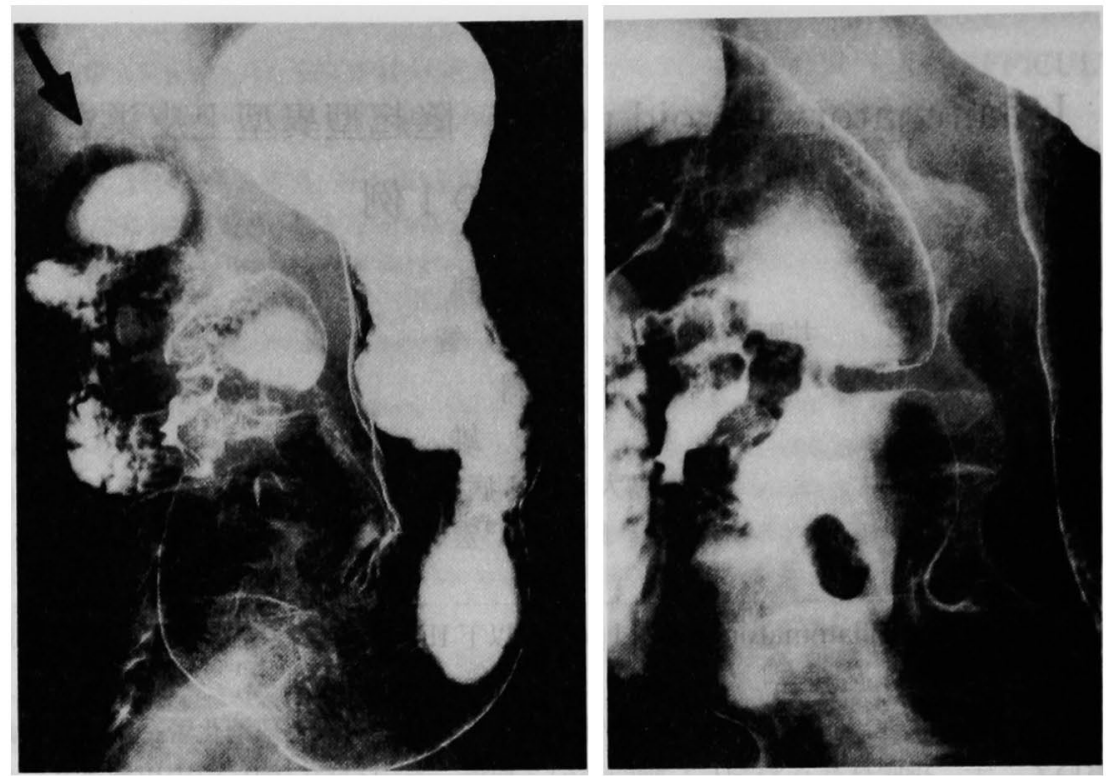

図 1 上部消化管造影所見：幽門部より十二指腸球部に及ふ2 2 型胃癌とその口側の卵 円形の隆起性病変を見る。左上の矢印は，十二指腸媳室を示す。

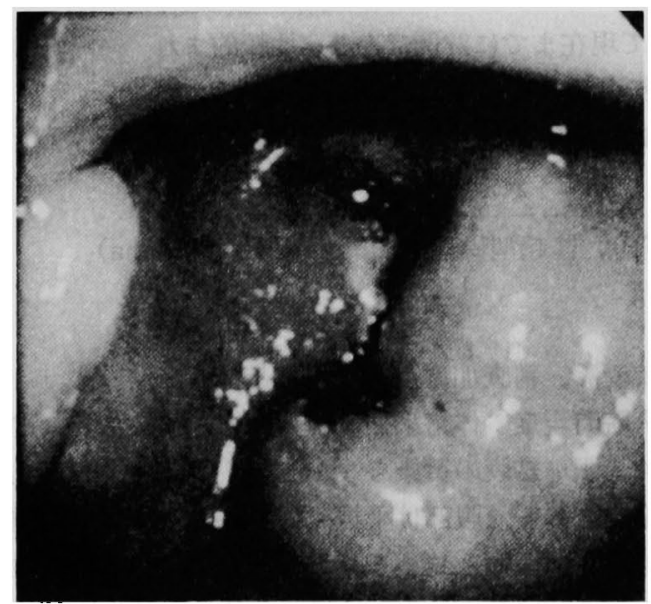

図 2 上部消化管内視鏡所見：ほぼ全周性に狭窄した 幽門部 2 型癌圭す。その口側に表面平滑なポリー プ病変を認める。

る 2 型癌を認めた。 また, 口側の隆起性病変は, 表面 平滑なるも明らかな茎を認めず，山田II型の過形成性 ポリープと考えられた（図1右）。

上部消化管内視鏡所見：幽門輪に覆いかぶさるよう に後壁から小䛾側を中心に，ほほ全周性の隆起面を認 め, 中心に潰瘍形成もみられ，2 型胃癌と考えられた。 その口側, 後壁やや大彎よりに軽度退色した表面平滑

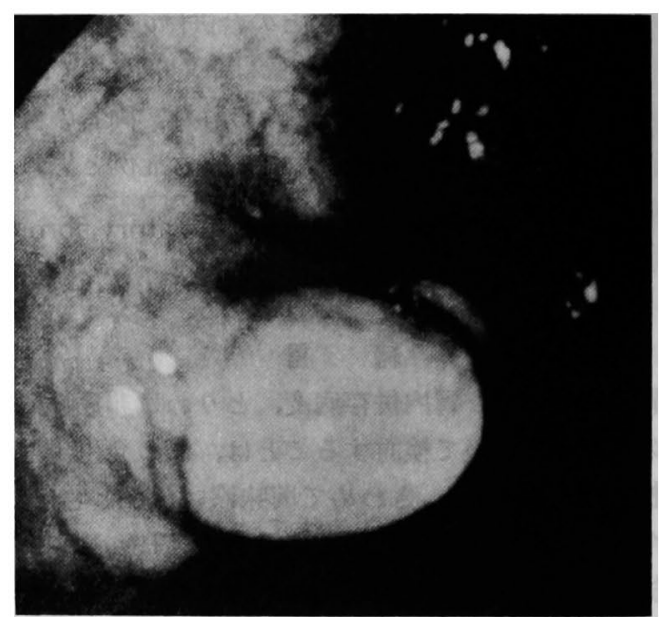

图 3 上部消化管内視鏡所見：色菜散布により，表面 粘膜は，ほほ正常の胃粘膜を呈し，胃粘膜下腫癔と 診断された。

なポリープ病変を認めた（図 2). 色素散布を行うと, ポリープ病変の表面は, ほほ正常の胃小区を呈してお り，過形成ポリープよりはむしろ，胃粘膜下腫瘦を疑 う所見であった（図3）。

さらに，胃体部小篹やや後壁よりに，小さな半球状 の隆起性病変を認め, 過形成性ポリープもしくは ATPの像であった（図4). 


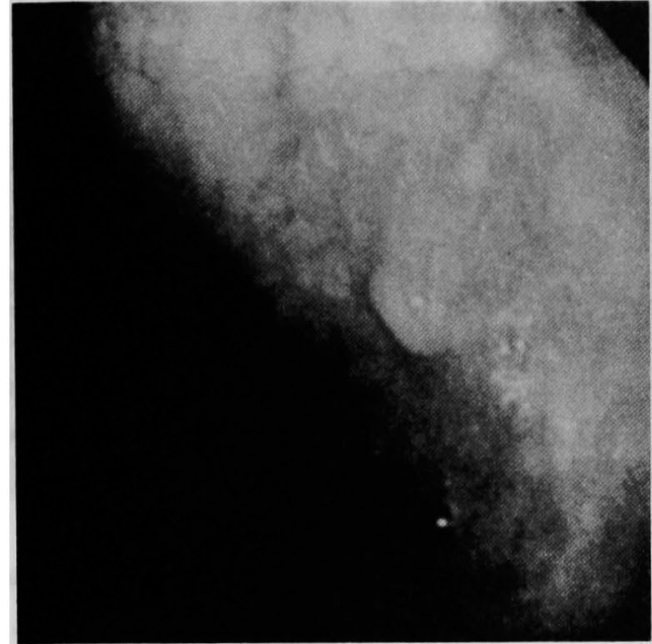

図4 上部消化管内視䇚所見：胃体部に小さな半球状 の隆起性病変を認める。

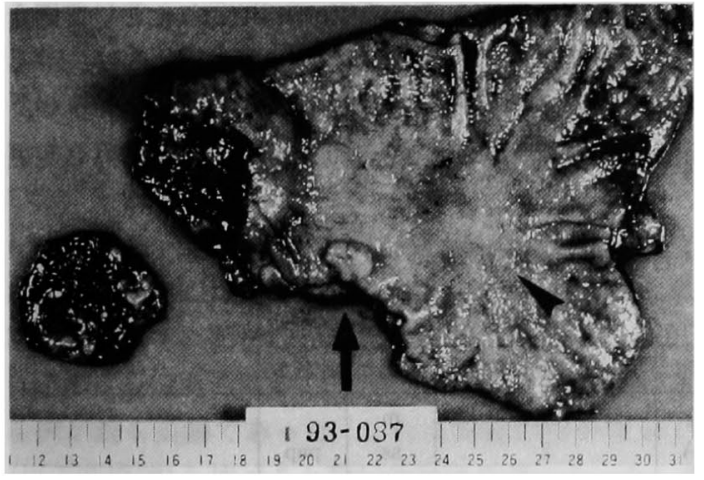

图 5 摘出標本：十二指腸球部へ浸潤した幽門部2 型 癌, その口側の粘膜下腫瘍 (矢印), 胃体部の ATP (くさび印)をそれぞれ認める. 左下は，十二指腸媳 室粘膜を示す。

以上より，過形成性ポリープまたは ATP と胃粘膜 下腫瘍を伴う 2 型進行胃癌との診断で, 胃亜全摘術 (B-I 法)，12，13番リンパ節を含めた 2 群郭清(D2)， 十二指腸䄸室切除術を行った。

摘出標本（図 5 )：十二指腸肛門側がややくずれてい るものの，ほほ全周に急峻な立ち上がりをもち, 明暸 な境界を有する周庭を認め，中心に浿锡形成を呈する 2 型進行胃癌を認めた。

そのやや口側の幽門前庭部後壁には，矢印にみられ るように，中央に小さなくびれを有し，胃粘膜により 覆われた粘膜下腫瘍性病変がみられた。
さらに，胃体部小績やや後壁には，図のくさび印に みられるような半球状の小隆起性病変を認め, ATP が示唆された。

なお，図の左下は，同時に切除された十二指腸悡室 粘膜を示す。

病理組織所見：2 型進行胃癌は, 整膜下層 (ss)にま で浸潤した中分化型管状腺癌 (tub2) で， $\mathrm{ly}_{0} ， \mathrm{v}_{0} ， \mathrm{n}_{0}$, ow (-), aw（一) であった（図6).

その口側の粘膜下腫瘍性病変は, 軽度に哓胞状に拡 張した腺管を伴う粘膜の下層に, 繊維細胞, 緎維芽細 胞の增殖を主体とした比較的均一な腫瘍を認め, 好酸 球，リンパ球を中心とした慢性炎症性細胞浸潤がみら れた．特に，リンパ球は一部で集合し，偽リンパ滤胞 状を呈していた(図7)，強拡大像では， spindle cell の

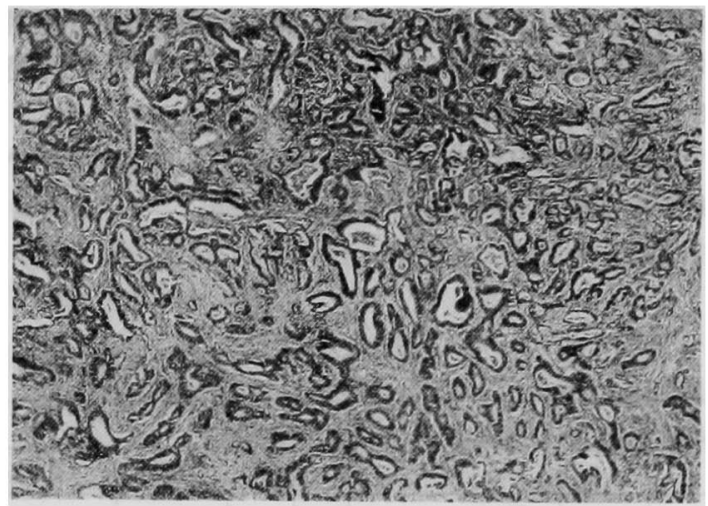

図 6 病理組織所見：癌腫は中等度に分化した管状腺 癌で，獎膜下層 (ss) までの浸潤がみられた（HE 染 色, × 40).

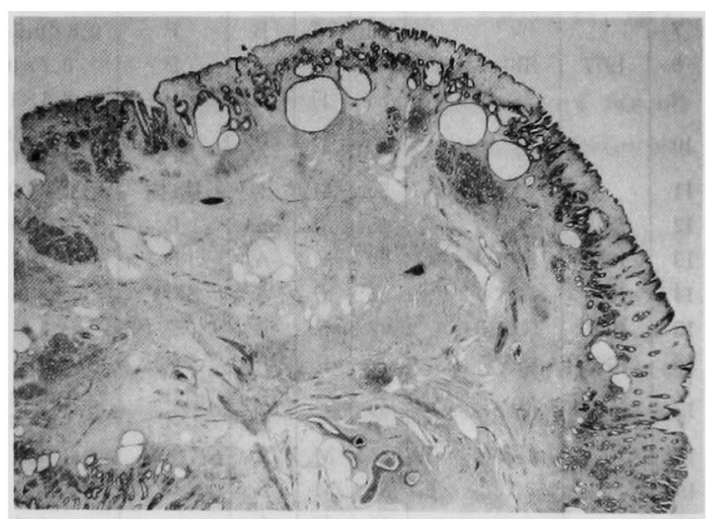

図 7 病理組織所見：粘膜下腫瘍は，粘膜下の線維細 胞, 線維芽細胞の増殖と慢性炎症性細胞浸潤が主体 である（HE-Victoria blue 重染色, ×10）。 


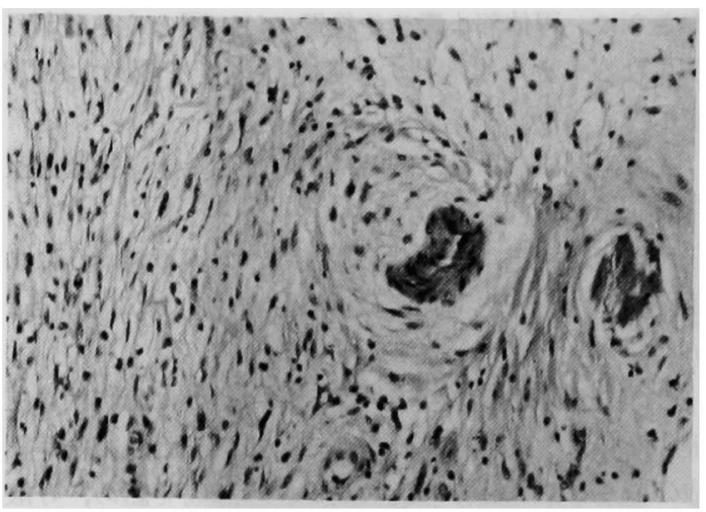

図 8 病理組織所見：小血管周囲には,いわゆる onion skin patternがみられる (HE-Victoria blue 重染色, $\times 200)$.

流円状からうず巻き状の配列を認め，特に小血管周囲 では，いわゆる onion skin patternを呈していた（図 8). 以上より, IFP と診断した.

胃体部の隆起性病変は, adenoma,いわゆる ATPで あった（図 9)。

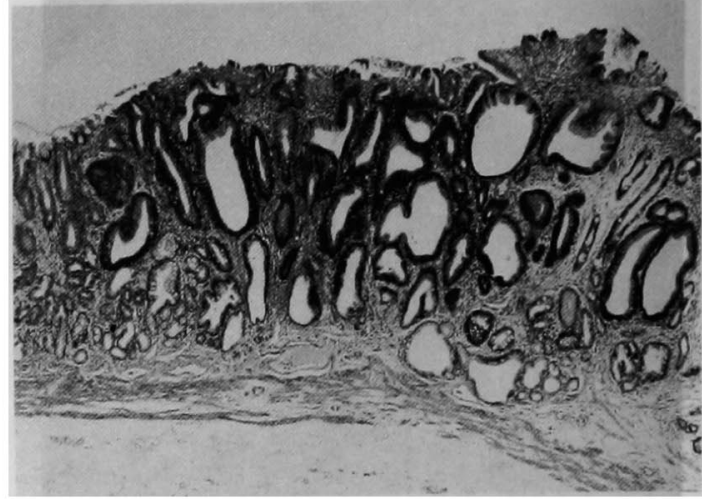

図 9 病理組織所見: 胃体部の隆起性病変は, adenoma, いわ他るであった（HE-Victoria blue 重染色, $\times 20)$.

\section{考察}

1949年, Vanek ${ }^{11} に よ り$, gastric submucosal granuloma with eosinophilic infiltration として紹介 された胃疾患は，その後, 1953年, Helwig らにより， 病因の主体が炎症にもとめられることより, inflammatory fibroid polyp (以下 IFP) と名称の変更

表 1 本邦における胃 IFP と胃癌の合併例

\begin{tabular}{|c|c|c|c|c|c|c|c|c|c|c|c|c|}
\hline \multirow{2}{*}{ No. } & \multirow{2}{*}{ 報告年 } & \multirow{2}{*}{ 報告者 } & \multirow{2}{*}{ 年龄 } & \multirow{2}{*}{ 性別 } & \multicolumn{3}{|c|}{ IFP } & \multicolumn{4}{|c|}{ 盘 } & \multirow{2}{*}{ 他 } \\
\hline & & & & & 部位 & 肉腿型 & 大きさ $(\mathrm{cm})$ & 部位 & 肉 眼 型 & 深達度 & 組織型 & \\
\hline 1 & 1967 & 遠城寺ら & 50 & $\mathbf{M}$ & A & & 1 & & 早期䅝 & $\mathrm{m}$ & & \\
\hline 2 & 1969 & 角田ら & 48 & $\mathbf{M}$ & A & $\mathbf{P}$ & $0.7 \times 0.8 \times 1.3$ & A & 2 & ss & pap & \\
\hline 3 & 1971 & 福土ら & 81 & M & A & $\mathbf{P}$ & & A & I & & & \\
\hline 4 & 1976 & 井上ら & & & A & $\mathbf{P}$ & & & 1 & & & \\
\hline 5 & & & & & A & $\mathbf{P}$ & & & IIC & & & \\
\hline 6 & & 䂭崎ら & 76 & M & A & $\mathbf{P}$ & $1.0 \times 0.8 \times 0.6$ & $\mathrm{~B}$ & 3 & se & por & \\
\hline 7 & & & 66 & $\mathbf{M}$ & B & $\mathbf{P}$ & $0.8 \times 0.5 \times 6.3$ & A & $\| c+11 a$ & $\mathrm{~m}$ & & ATP 件存 \\
\hline 8 & 1977 & 田中ら & 46 & $\mathrm{~F}$ & A & $\mathbf{P}$ & $0.7 \times 0.7$ & B & II + IIb & $\mathrm{m}$ & tub2 & 過形成性ポリープ併存 \\
\hline 9 & & & 56 & $\mathrm{~F}$ & A & $\mathrm{P}$ & $2.5 \times 1.5$ & $\mathrm{~B}$ & II + Il $c$ & sm & sig & \\
\hline 10 & & & 73 & $\mathrm{~F}$ & $\stackrel{A}{A}$ & $\stackrel{P}{P}$ & $\begin{array}{l}0.4 \times 0.4 \\
0.5 \times 0.5\end{array}$ & $\mathrm{~B}$ & 2 & ss & por & 2 ケの IFP \\
\hline 11 & & & 50 & $\mathbf{M}$ & A & IIa 様 & $0.7 \times 0.7$ & A & II $c+$ III $(+$ IIa $)$ & $\mathrm{m}$ & tub2 & 两者重なって \\
\hline 12 & 1979 & 今吉ら & 65 & $\mathbf{M}$ & ang & $\mathrm{P}$ & $2 \times 1 \times 1$ & $\mathrm{C}$ & IIa & $\mathrm{m}$ & tub2 & \\
\hline 13 & 1986 & 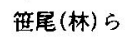 & 60 & $\mathbf{M}$ & A & $\mathrm{P}$ & $4.5 \times 3.0 \cdot 2.5$ & $\mathrm{~B}$ & 3 & ss & tub2 & \\
\hline 14 & 1989 & 鈴木ら & 56 & M & A & SMT & $1 \times 0.7$ & ang & IIc & $\mathrm{sm}$ & tub2 & \\
\hline 15 & 1991 & 久保田ら & 42 & $\mathrm{~F}$ & B & $P$ & 3 & ang & $\mathrm{IIC}+\mathrm{III}$ & m & sig & 両者接して \\
\hline 16 & 1992 & 松田 5 & 72 & $\mathrm{~F}$ & A & $P$ & 1.5 & ang & IIc & & tub2 & \\
\hline 17 & & 森ら & 69 & $F$ & $\begin{array}{l}\mathrm{B} \\
\mathrm{B}\end{array}$ & $\begin{array}{l}\text { NP } \\
\text { NP }\end{array}$ & $\begin{array}{l}1.4 \times 0.6 \\
1.2 \times 0.4\end{array}$ & B & IIC & $\mathrm{sm}$ & por & $\begin{array}{l}2 ケ の \text { IFP } \\
\text { 両者重なって }\end{array}$ \\
\hline 18 & & 浜家ら & 64 & $\mathrm{M}$ & A & & 1.0 & & & & & \\
\hline 19 & & & 58 & $\mathrm{M}$ & B & & 0.5 & & & & & \\
\hline 20 & & & 67 & $\mathrm{~F}$ & A & & 0.6 & & & & & \\
\hline 21 & & & 68 & $\mathrm{~F}$ & A & & 0.7 & & & & & \\
\hline 22 & 1994 & 展本ら & 81 & $\mathrm{~F}$ & A & SMT & $1.5 \times 1.0 \times 1.0$ & $\mathrm{AD}$ & 2 & ss & tub2 & ATP 併存 \\
\hline
\end{tabular}

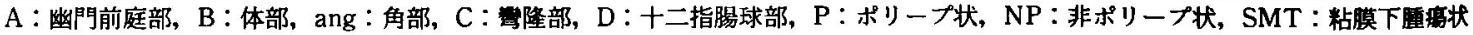


がなされ，現在，これが最も一般的に用いられるよう になっている.

胃 IFP の病理組織学的所見として,Vanek ${ }^{11}$ は，1) 織維茅細胞, 緎維細胞の粗な膠原緎維内の增生, 2) 好 酸球, リンパ球などの非特異的炎症細胞浸潤やリンパ 渚胞の形成, 3）小動脈, 毛細血管, リンパ管の増生と 拡張を認める，とし，さらに Helwig' ${ }^{2}$ はこれに加えて， 4）小血管を中心とした緎維性結合織の同心円状配列 (onion skin pattern) をあげている.

その後, 疾患の増加に伴い, 病理組織学的に IFPに 類似した好酸球のびまん性浸潤を呈し, 全身のアレル ギー性素因とも関連する一連の疾患に対し，Johnstone ら し，IFPとはまったく異なった entity の疾患であると されるようになった。

胃 IFP は, 山邊ら゙にによれば, 1990年までに本邦にお いて38例の報告があり，50歳代に多く，男女比 $1.6 ： 1$ と男性に多く，74\%が前庭部に認められ，大きさ $4 \mathrm{~cm}$ 末満が84\%を占め, 粘膜または粘膜下層より発生した ものが多かった, と述べ,さらに，有荎性のものが $46 \%$ にみられ，ほとんどはポリープとの術前診断を受けて いた，と報告している。

胃 IFP と胃癌との合併例は, 著者らの調へた限りで は，現在までに21例の報告がみられた ${ }^{5)-18) . こ れ ら に ， ~}$ 本症例を加え, 22例の検討を行った（表 1 )。

年齢は42歳から81歳, 平均62.4歳であり, 著者らの 症例が最も高齢であった。これは胃癌非合併胃 IFP $^{4}$ (以下非癌例) と比べると約10歳程度高龄であった。男 女比は, $1.2 ： 1$ と非癌例同様やや男性に多くみられ た. IFP の存在部位は, 幽門前庭部が18例（75\%）と 最も多く，非癌例と同様の結果が得られた.IFPの肉 眼型は,いわゆるポリープ状を呈したものが最も多く, 14例（74\%）にみられた。本症例のように粘膜下腫瘍 状の形態を呈したものは，2例のみであった．IFPの 大きさを長径において比較すると, $1 \mathrm{~cm}$ 以下のもの 12 例 $(60 \%), 2 \mathrm{~cm}$ 以下のもの 5 例 $(25 \%), 2 \mathrm{~cm}$ を越え

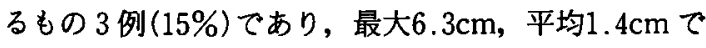
あった.これは,非癌例に比較すると小さい傾向にあっ た.

次に，胃癌部についてみると，胃癌は幽門前庭部に 5 例 $(33 \%)$, 胃角部に 3 例 (20\%), 胃体部 6 例 $(40 \%)$, 胃彎隆部に 1 例 (7\%) に認められた。IFP との関係 では，胃癌が IFP の口側に存在するものが多かった。 早期癌が13例， $72 \%$ と多く，中でも，12例中 4 例が隆
起型であった．組織型では，未分化型 5 例，分化型 7 例と両者ほぼ半数ずつであった。

他の併存病変としては, ATPが 2 例に, 過形成性ポ リープが1例に認められた。

IFP と胃癌においては, 両者が重なって存在したも のが 2 例, 両者が接して存在したものが 1 例であり, 他は離れて認められた。

IFP と胃癌との因果関係については, 田中ら 病変が同一胃内に無関係に相前後して偶然に発生した とみなすのが妥当と述へているが, 角田ら゙は癌が IFP を生じる炎症刺激となったと推定しており,一定 の見解をみない.

しかしながら, 胃癌における非癌性胃内併存病変を 検討すると, ATPやポリープといった隆起性病変を 併存する胃癌では, 隆起型胃癌を発生しやすく, 併存 病変の形態を模倣するように発育進展する傾向も伺わ

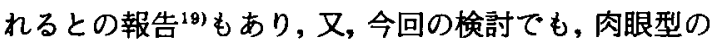
はっきりした早期胃癌は術中 4 例に隆起型癌の発生が みられ，これは一般の早期胃癌に比べ隆起型の割合が 高率であり ${ }^{20)}$, IFP が胃癌の粘膜背景としての役割り を担うのか否か, 興味の持たれるところと考える.今 後の症例の集積を期待したい.

\section{結語}

比較的な胃 IFPとATPを伴存した胃癌の興味あ る症例について報告した。 また, 胃 IFP と胃癌との併 存例の本邦報告例について文献的考察を加えた。

なお, 本論文の要旨は第67回日本消化器内視鏡学会中国 四国地方会（松江）において発表した。

$$
\text { 文献 }
$$

1) Vanek J : Gastric submucosal granuloma with eosinophilic infiltration. Am J Pathol 25 : 397411, 1949

2) Helwig EB, Ranier A : Inflammatory fibroid palyps of the stomach. Surg Gynecol Obstet 96 : 355-367, 1953

3) Johnstone JM, Morson BC: Inflammatory fibroid polyp of the gastrointestinal tract. Histopathol $2: 349-361,1978$

4) 山息和生, 荻野信夫, 小川法次地: 巨大な胃 inflammatory fibroid polyp の 1 例. 日臨外医会 誌 $51: 1972-1975,1990$

5）遠城寺宗知, 海江田純：胃の好酸性芽腫, とくに奇 生虫性肉芽腫との鑑別. 日病理会誌 $56: 192-$ 193, 1967

6）角田秀雄, 三上忠英, 保坂 剛他：胃の好酸性肉芽 
腫 (inflammatory fibroid polyp) $の 2$ 例. 癌の臨 $15: 805-810,1969$

7）福士経雄, 佐藤貞治, 西沢諒一他：早期胃癌に伴っ た inflammatory fibroid polyp $の 1$ 例. 弘前医 $23: 284-285,1971$

8）井上義明, 增田久之, 井上修一他：Inflammatory fibroid polyp 04 症例. 日消病会誌 $73: 209$, 1976

9）磯崎博司, 松井武志, 并上 徹他：胃好酸性肉芽腫 の 3 例. 日消病会誌 $73: 893,1976$

10）田中貞夫, 坂江清弘, 徳永正義: 胃の inflammatory fibroid polyp と併存した胃癌の 4 例について。癌の臨 $23: 1355-1359,1977$

11）今吉英介，野村修一，加地信彦他：胃の inflammatory fibroid polyp と早期癌の合併例. 外科 $41: 1507-1510,1979$

12）笹尾折郎，金 隆史，西廻和春他：胃癌と併存した 胃好酸球性肉芽腫 (inflammatory fibroid polyp) の 1 症例。広島医 $39: 1315,1986$

13）林雄三, 笹尾哲郎, 日高徹他：胃の inflammatory fibroid polyp $の 3$ 例. 広島医 39 : $1408-1413,1986$
14）鈴木誠治，鈴木謙三，福嶋 貫地：胃 inflammatory fibroid polyp (早期胃癌合併症例を 含む) 22 例. Gastroenterol Endosc $31: 499,1989$

15）久保田博也, 藤本正夫, 春日井達造他：宿凹型早期 胃癌と胃好酸球性肉芽腫の合併例. 画像診断 11 : 1344-1349, 1991

16）松田和也, 内田䍰仁, 田村香織他：早期胃癌, 過形 成性ポリープを伴った胃好酸球性肉芽腫症 (inflammatory fibroid polyp) の 1 症例. 臨と研 $68: 1749-1753,1992$

17) Mori M, Kakeji $Y$, Adachi $Y$, et al: Nonpolypoid inflammatory fibroid polyps concomitant with early carcinoma in the stomach. Europ J Surg Oncol 18: 632-635, 1992

18）浜家一雄, 能势聡一郎：胃の inflammatory fibroid polyp 21 例の細胞学的検索. 岡山济生会病 誌 $24: 37-43,1992$

19）廣本雅之, 安井 昭, 西田佳昭他：胃内併存病変を 有する胃癌切除例の検討. 昭和医会誌 50 ：7681,1990

20）三輪 潔：全国胃がん登録調查報告. 第34号, 胃呙 研究会, 東京, 1994

\title{
A CASE OF GASTRIC CANCER WITH INFLAMMATORY FIBROID POLYP AND ATP (ADENOMA)
}

\author{
Masayuki HIROMOTO, Chiaki INOKUCHI, Makoto OCHI, Osamu SANADA, \\ Tomoo MATSUDA* and Hiroshi YOKOZAKI** \\ Department of Surgery and Internal Medicine*, Inokuchi Hospital \\ First Department of Pathology**, Hiroshima University, School of Medicine
}

We experienced a relatively rare case of gastric cancer with inflammatory fibroid polyp (IFP) and ATP (adenoma) of the stomach.

An 81-year-old woman was seen at the hospital because of abdominal distention and watery diarrhea. Upper gastrointestinal series and endoscopy revealed a type 2 cancer of the pylorus invading the duodenal bulb, a spherical submucosal tumor mimicking Yamada's type III polyp at slightly oral-side from the first lesion, and a small hemispherical elevated lesion in the lesser curvature of the body of the stomach. Subtotal gastrectomy was performed. Histopathologically these lesions were moderately differentiated gastric cancer (tub2, ss), IFP, and ATP, respectively.

We rarely encounter a case of gastric cancer with IFP of the stomach and 22 such case have been reported in the Japanese literature so far. An average age was 62.4 years. It was slightly predominant in men, most IFPs were less than $1 \mathrm{~cm}$ in diameter, and the gastric cancers were commonly in an early stage. There are many hypossess about this association of both diseases. It is though that this case is suggestive in terms of mucosa background of the gastric cancer. 